Original Research Article

\title{
Students Positive Response on Semantic Mapping Strategy in English Writing Skill
}

\author{
Ulfa Wulan Agustina ${ }^{1}$, Luluk Choirun Nisak Nur ${ }^{2}$ \\ 1,2 English Department, KH.A. Wahab Hasbullah
}

Article History:

Submitted: $21^{\text {st }}$ July 2018, Accepted: $27^{\text {th }}$ September 2018, Published: $15^{\text {th }}$ October 2018

\begin{abstract}
One of the most important skills in English is writing. The writing skill allows the students to express and investigate ideas, thoughts, and beliefs and make them apparent and obvious. Writing encourages writers to think, learn and communicate. Unfortunately, most of the students were difficult and get bored in writing activities. They need some strategies to make easier when they do writing task. Semantic mapping is one of good ways for writing task. It helps students to get idea and improve it into sentences and paragraphs. The purpose of the research is to know whether semantic mapping strategy is able to improve writing skill. This study focus on students positive response on semantic mapping strategy in English writing skill. The instrument of this study is using questionnaire which is distributed to the students of second semester in English Department at an Indonesian private university which consisted of 30 students. The result of this study are $25 \%$ of student get easier in learning writing task and $75 \%$ are motivated to have a good writing by using semantic mapping strategy.
\end{abstract}

Keywords: semantic mapping; students response; writing skill.

HOW TO CITE: Agustina, U. \& Nur, L. (2018). Students Positive Response on Semantic Mapping Strategy in English Writing Skill. JEES (Journal of English Educators Society), 3 (2), 189-196. doi: https://doi.org/10.21070/jees.v3i2.1560

\section{Introduction}

English has four basic skills they such as speaking, listening, reading, and writing. Passive skill consist of listening and reading skill, while as active skills are consist of writing and speaking skill. The four skills are important in learning English. One of the four skills of English is writing skill. Writing is an activity which needs more complex steps. Writing is complicated activity that requires intense concentration.

Nowadays, there is the fact is some students have low achievement in writing English. It causes writing is long process, so it needs concentration, instruction, practice and patience.

*Coresponding author.

E-mail address: ulfawulanagustina@,unwaha.ac.id

Peer reviewed under reponsibility of Universitas Muhammadiyah Sidoarjo.

(C) 2018 Universitas Muhammadiyah Sidoarjo, All right reserved, This is an open access article under

the CC BY license (http://creativecommons.org/licenses/by/4.0/) 
Those reasons make some of students bored to write. Another reason is they always confused how to start writing and lost their idea when they start writing. In this case, the researcher uses the strategy to help students to find idea and start writing smoothly. Semantic mapping can help students to map their idea and develop it into sentences (Oxford, 1990)

Semantic mapping is declared as one of an active learning strategy which recommended for students in writing task. Canas \& Novak (2006) defined concept mapping as "graphical tools for organizing and representing knowledge. Concept mapping can be a knowledge representation. It becomes a tool actively used by students during learning. The process of concept mapping not only demands active involvement of the learner in the learning, but also sheds light on their understanding of a specific learning area.

Semantic mapping can help students to classify their idea into some flowchart or drafts. Afterward they write their sub ideas of the main idea and explore some vocabulary which they use to make an essay. Later they can develop it into some sentences and paragraph. Moreover, the concept map is a special form the web diagram to explore some knowledge gathering and sharing information. Semantic mapping is a kind of strategy that made and shows the key word and concept of the text that related each other by drawing a graphic word. The framework of semantic mapping includes the concept word, two categories and other examples.

According to Mori (1993) some instructional of semantic mapping are : a) select a word central to the topic b) display the target word c)invite the students to generate as many words as possible d)have the student write the generate words in categories. e) From the list construk the map

The Implementation of semantic mapping strategy as follows:

a) Introducing the theme

The researcher introduce the theme of the units and draw large oval with the theme inside it on the black / white board then display a picture which related to the theme.

b) Brainstorming

The researcher asks the students about some question to stimulate the information from students that related to the theme or topic.

c) Categorizing

Asks students to make categories that are seeing relationship among the word. Then make some sub idea of the paragraph.

d) Personalizing the map 
The students make map in their books. The students decide the word or vocabularies they use in every sentence and then develop into paragraph

e) Post assignment

The students develop their map word or vocabularies into some sentence or paragraph which is they have prepared before.

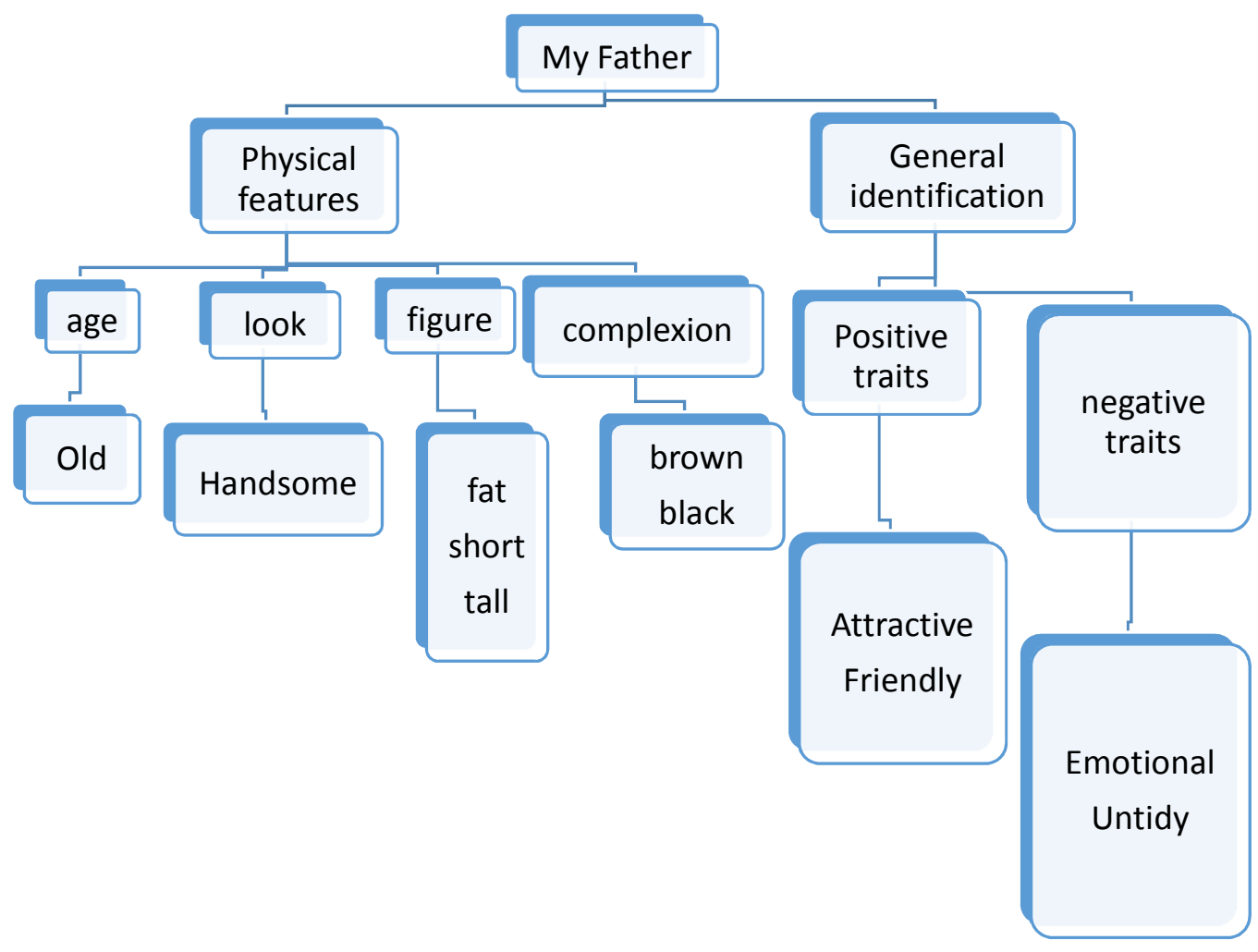

Figure 1. Semantic Mapping Diagram

Moreover, Nofrianti (2017) found that The implementation of the Semantic Mapping technique in the essay writing class improved the researcher's performance and also the students' activities. The previous studies was focus on the impact of semantic mapping and the students' value after semantic mapping implementation. It was not focus on students' response about implementation of semantic mapping strategy. Based on previous statement, students' response about the strategy being the focus of this study and the purpose is to know how far the strategy can motivate and help the students on writing skill. 


\section{Methods}

This study focuses about the implementation of semantic mapping for writing in the classroom and how about students respond to the implementation of semantic mapping in class. This research is qualitative descriptive research because it focuses on description and explanation. This study focuses on language education program in the fourth semester. Questionaire instrument was used to collect the data. Students were asked to fill the questionnaire. The answers then will be used to measure the response of the implementation of semantic mapping for writing class. The questionnaire consisted of ten questions covering 4 topics on learning English. The first topic contains their interest about English lesson. The second and third topic about how often they write about English. Then, the next topic about their feeling when they start to write and how about their idea for writing (4 and 5). The other topic is discuss about semantic mapping and their response through semantic mapping. Here is the questionnaire about using semantic mapping strategy? (Select an answer by checking $(\sqrt{ }$ ) the answer option).

Table 1. The questionnaire used for observing students response on Semantic Mapping

\begin{tabular}{|c|c|c|c|c|}
\hline Questions & agree & $\begin{array}{c}\text { Strongly } \\
\text { agree }\end{array}$ & disagree & $\begin{array}{l}\text { Stongrly } \\
\text { disagree }\end{array}$ \\
\hline 1. Do you like English? & & & & \\
\hline 2. Do you often write an English essay? & & & & \\
\hline 3. Is it difficult to write English essay? & & & & \\
\hline $\begin{array}{l}\text { 4. Do you feel bored when you have writing } \\
\text { task? }\end{array}$ & & & & \\
\hline $\begin{array}{l}\text { 5. Is it difficult to find some idea in writing } \\
\text { task? }\end{array}$ & & & & \\
\hline $\begin{array}{l}\text { 6. Do you often lost your idea and forget } \\
\text { your idea when writing? }\end{array}$ & & & & \\
\hline $\begin{array}{l}\text { 7. What do you know about semantic } \\
\text { mapping? }\end{array}$ & & & & \\
\hline $\begin{array}{l}\text { 8. How do you feel when you write by using } \\
\text { semantic mapping? }\end{array}$ & & & & \\
\hline $\begin{array}{l}\text { 9. Is semantic mapping is the best way to } \\
\text { start writing? }\end{array}$ & & & & \\
\hline $\begin{array}{l}\text { 10. Is semantic mapping motivating you to } \\
\text { have writing task more and more? }\end{array}$ & & & & \\
\hline
\end{tabular}




\section{Findings and Discussion}

This part presents the findings and the discussion of the study. It concerns with the implementation of Semantic Mapping through writing skill. This study focus on students' response about semantic mapping.

The questionnaire was distributed at the last meeting (fourth meeting) after conducted test exactly on May 16th, 2018. The researcher used questionnaire to know students' response about semantic mapping. After giving the questionnaire the researcher found the result for the first question on questionnaire there were 20 or $66.67 \%$ students of 30 students answered agree that they were interested in learning English especially writing skill and 7 or $23.3 \%$ students answered strongly agree, and 3 or $10 \%$ of students answered disagree. No students answered strongly disagree. Then for the second question on questionnaire there were 13 or $43.33 \%$ students of 30 students answered agree that they were often doing the essay writing the class and 16 or $53.33 \%$ students answered strongly agree, and 1 or $3.33 \%$ of students answered disagree. No students answered strongly disagree.

For the next result of the third question on questionnaire there were 15 or $50 \%$ students of 30 students answered agree that the feel difficult in writing English essay and 14 or $46.67 \%$ students answered strongly agree, and 1 or $3.33 \%$ of students answered disagree. No students answered strongly disagree. The fourth question on questionnaire also there were 15 or 50\% students of 30 students answered agree bored when doing the writing task and 15 or $50 \%$ students answered strongly agree. No students answered disagree and strongly disagree.

Furthermore, the result of the fifth questions on questionnaire were 14 or $46.67 \%$ students of 30 students answered agree that they difficult to find some idea for writing task and 13 or $43.33 \%$ students answered strongly agree, and 2 or $6.67 \%$ of students answered disagree and 1 or $3.37 \%$ students answered strongly disagree. The sixth question on questionnaire were 15 or $50 \%$ students of 30 students answered agree that they often forget or lost their idea in the middle of writing task and 11 or $36.67 \%$ students answered strongly agree, and 4 or $14,33 \%$ of students answered disagree. No students answered strongly disagree.

For the next result were were 12 or $40 \%$ students of 30 students answered agree they know about semantic mapping before and 16 or $53.33 \%$ students answered strongly agree, and 1 or $3.33 \%$ of students answered disagree, and 1 or $3.33 \%$ students answered strongly disagree which found on the seven question on questionnaire. The next data at eight question on questionnaire were found 18 or $60 \%$ students agree that they feel easy to write by using 
Semantic Mapping Strategy and 9 or 10\% students answered strongly agree, and 9 or $10 \%$ of students answered disagree and 1 or $3.37 \%$ students answered strongly disagree.

The next questionnaire were found 18 or $60 \%$ students answered agree that semantic mapping is the best strategy for writing task and $26.67 \%$ students answered strongly agree, and 4 or $14.33 \%$ of students answered disagree and no students answered strongly disagree this result found on ninth questionnaire and there were 20 or $66.67 \%$ students of 30 students answered agree that they were motivated for in learning English especially writing skill after they know about semantic mapping and 7 or $23.3 \%$ students answered strongly agree, and 3 or $10 \%$ of students answered disagree. No students answered strongly disagree this result found on tenth questionaire.

More data showing student's attitude toward implementation of Semantic Mapping strategy can be seen in Figure 1.

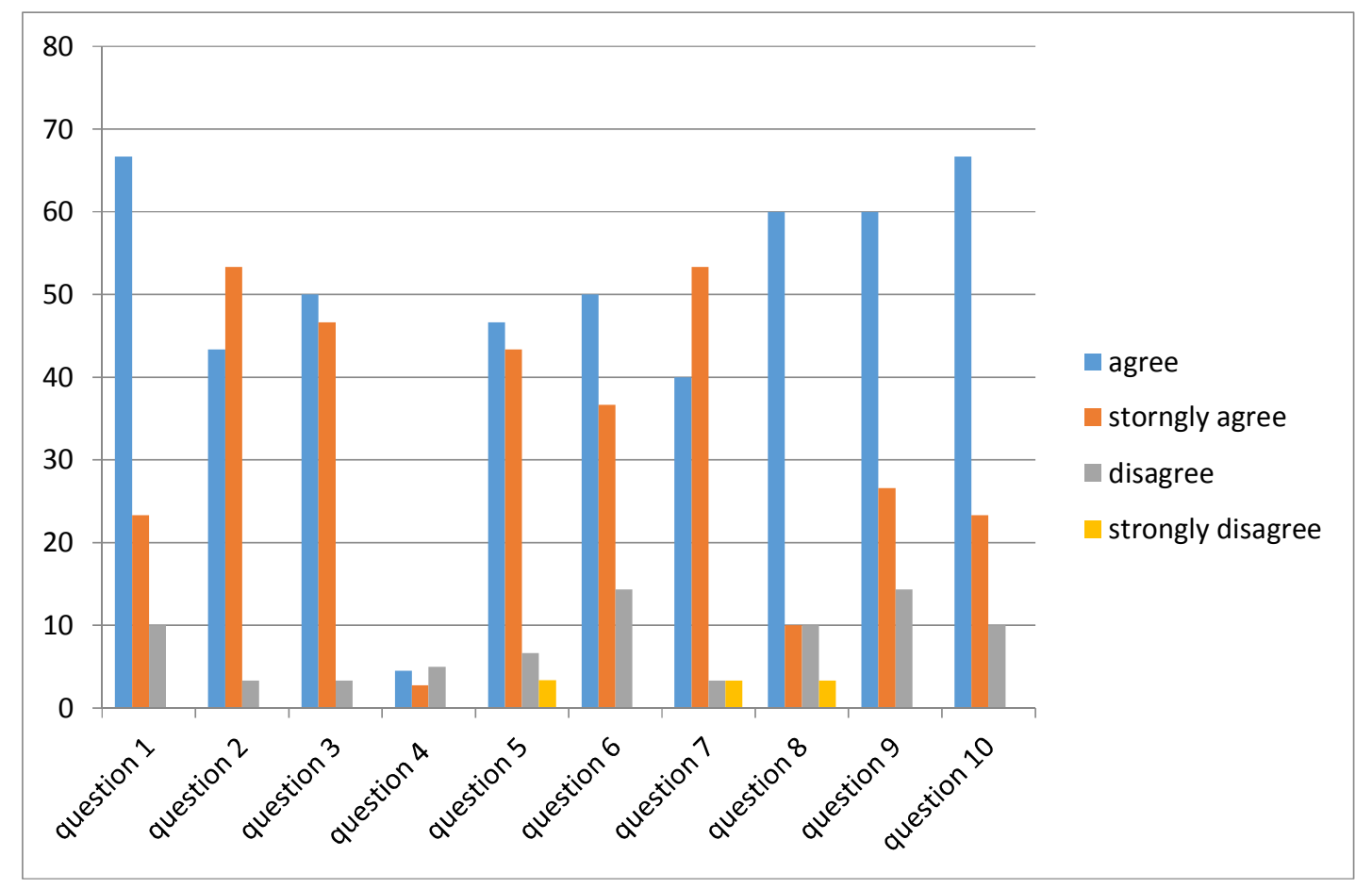

Figure 1. The result of students positive response on semantic mapping strategy

According the data in Figure 1, some students not only got easier in writing task but also motivated to write well. This result in line with Al-Sidalani \& Abdulrahman (2016) who said that semantic mapping as one of good strategy to motivated and help the students on writing task. This strategy is effective to help student in writing task. 
This study also related on previous study by Agustina, Ngadiso, \& Rochsantiningsih, (2013) who state that semantic mapping not oly help student to write but also to read well. Semantic mappping can be applyed to another English Skill.

In addition Siddiq (2013) state The finding of the study by using semantic mapping could improve the students' writing skill. This statemnet was prove by the result of the test and also the students response. Moreover, Nofrianti (2017) found that The implementation of the Semantic Mapping technique in the essay writing class improved the researcher's performance and also the students' activities.

\section{Conclusions}

Based on the result of quetionairre sheet, it is show that $25 \%$ students got easier in writing skill and $75 \%$ other were motivated to improve their writing well. The students' improvement writing skill can be seen from the value of student writing activities and also the result of the questionnaire. Almost students were motivated to write more after they know about semantic mapping strategy. The students can manage their vocabularies and idea easily by using semantic mapping. It almost helped them when doing writing activities. They enjoyed the learning activity and felt interested to write in English which had been very hard to do previously. In a nutshell, we can say that semantic mapping strategy can improve students' writing skill activities, especially in recount text. To support the result of this study, future research in another genre of text is suggested to conduct to get more empirical data in developing theoretical and practical knowledge of semantic mapping.

\section{Acknowledgments}

I would thank to all who has support me to finish this journal especially from the first process until I can finish it well.

\section{References}

Agustina, Y., Ngadiso, N., \& Rochsantiningsih, D. (2013). The Effectiveness of Semantic Mapping to Teach Reading Viewed from Students' Intelligence. English Teaching, 1(1), $23-36$.

Al-Sidalani, \& Abdulrahman, H. (2016). The Effect of Using Semantic Concept Mapping Strategy on Developing the Writing Skill of EFL Female Secondary. Journal Taibah 


\section{University : Departement of Curriculum Method.}

Canas, A. J., \& Novak, J. D. (2006). Concept Maps: Theory, Methodology, Technology. In Proceedings of the Second International COnference on Concept Mapping. Retrieved from http://philapres.org/reg/CANCMT

Mori, M. (1993). Semantic Mapping.

Nofrianti, E. (2017). Improving Essay Writing using the Semantic Mapping Technique. English Education Journal (EEJ), 8(1), 44-54.

Oxford, L. R. (1990). Language Learning Strategies. The university of Albama : Heince and heinc publisher.

Siddiq, A. (2013). The Use Of Semantic Mapping Tecnique To Improve Writing Skill In The Descriptive Text FKIP Unisma. JP3, 1(12). 